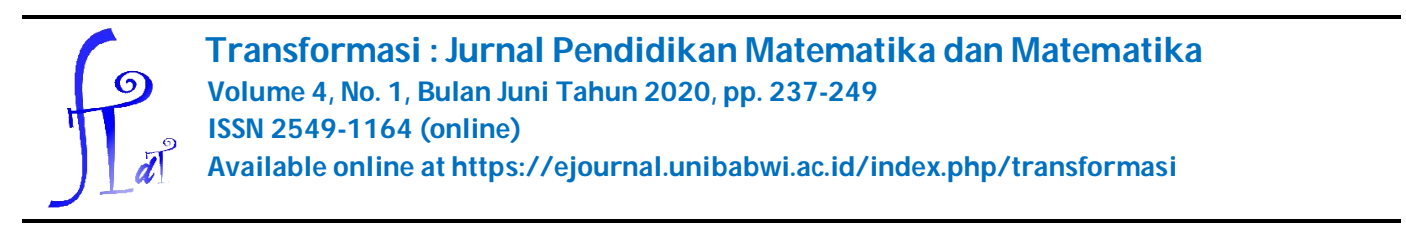

\title{
BERPIKIR KRITIS DALAM PEMECAHAN MASALAH OPEN-ENDED DITINJAU DARI KECEMASAN MATEMATIKA
}

\author{
Renata N. R. Jannah', Priza T. S. Wicaksana2 ${ }^{2}$, Linda Kartikasari³, \\ Shofan Fiangga ${ }^{4}$ \\ 1,2,3,4 S1 Pendidikan Matematika, Universitas Negeri Surabaya \\ e-mail korespodensi : renalaily77@gmail.com
}

Diterima : 20-05-2020, Revisi: 09-06-2020, Diterbitkan : 26-06-2020

\begin{abstract}
ABSTRAK
Penelitian ini bertujuan untuk mengetahui tahap berpikir kritis siswa dalam menyelesaikan soal open-ended dilihat dari tingkat kecemasan siswa. Penelitian diawali karena adanya siswa di sekolah yang sering merasa takut atau muncul kegelisahan ketika bertemu dengan pelajaran matematika. Akibatnya siswa belum dapat maksimal memecahkan suatu masalah matematika yang diberikan guru saat dikelas. Kecemasan siswa dalam matematika adalah perasaan siswa yang muncul karena siswa kurang tertarik terhadap pelajaran matematika. Metode yang digunakan dalam penelitian ini adalah penelitian deskriptif dengan pendekatan kualitatif. Subjek penelitian adalah tiga siswa dengan kemampuan berpikir kritis dan masing-masing memiliki tingkat kecemasan rendah, sedang, dan tinggi. Analisis data dilakukan secara kualitatif dengan langkah : reduksi data, penyajian data, dan penarikan kesimpulan. Hasil penelitian menunjukan bahwa siswa berkategori rendah lebih mampu melakukan perencanaan masalah dan merumuskan strategi penyelesaian masalah dibandingkan siswa berkategori tinggi dan sedang.

Kata kunci : pemecahan masalah, masalah open-ended, berpikir kritis Facione.
\end{abstract}




\begin{abstract}
The purpose obtained in this study is to determine the stage of students' critical thinking in solving open-ended problems viewed from the level of student anxiety. The study began because students at school often felt fear or anxiety appeared when they met mathematics. As a result students have not been able to optimally solve a mathematical problem given by the teacher in class. Students' anxiety in mathematics is students' feelings that arise due to lack of student interest in mathematics. The method used in this study is a descriptive research with a qualitative approach. The subjects were three students with critical thinking skills and each has a low, medium and high anxiety levels. Data analysis was performed qualitatively with steps : data reduction, data presentation, and drawing conclusions. The results showed that low categorized students were better able to plan problems and formulate problem solving strategies than high and medium categorized students.
\end{abstract}

Key words : problem solving, open-ended problem, Facione critical thingking.

\title{
Pendahuluan
}

Masyarakat Indonesia di era globalisasi saat ini, banyak mendapatkan pengaruh dari luar, seperti semakin berkembang pesatnya pengetahuan dan teknologi yang mempengaruhi setiap aspek kehidupan masyarakat. Dalam mengimbangi hal tersebut diperlukannya pendidikan yang menjadi salah satu faktor yang berperan penting. Oleh karena itu, diperlukan upaya perbaikan sistem pendidikan di Indonesia untuk menyiapkan sumber daya manusia (SDM) yang berkualitas. Untuk memenuhi sumber daya manusia yang berkualitas dibutuhkan kemampuan berpikir kritis, logis, sistematis, dan kreatif. Di Indonesia, kemampuan berpikir kritis siswa masih rendah. Hal ini ditunjukkan pada hasil PISA tahun 2018 bahwa Indonesia berada pada peringkat 73 dari 77 negara. Menurut Facione (2011) kemampuan mendasar dari berpikir kritis adalah kemampuan interpretasi, analisis, evaluasi, inferensi, menjelaskan, dan regulasi diri. Oleh karena itu, untuk mengasah kemampuan berpikir krisis siswa dibutuhkan peran guru secara konsisten dan tersruktur mengenai penerapan matematika dalam kehidupan sehari-hari (Azikovith-undi \& Cheng, 2015). Sehubungan dengan itu, Shimizu (2000) dan Yamada (2000) melakukan penelitian yang menunjukkan hasil pentingnya peran guru dalam proses belajar melalui pemberian motvasi, pengungkapan, serta mengembangkan proses berpikir matematis siswa. Dengan begitu guru sebagai fasilitator 
diharapkan dapat mendorong, mengaktifkan dan mengembangkan berpikir kritis siswa, salah satunya melalui pembelajaran matematika.

Polya (1973) mengemukakan bahwa pemecahan masalah merupakan suatu aktivitas intelektual yang sangat tinggi sebab dalam pemecahan masalah siswa harus dapat menyelesaikan dan menggunakan aturan-aturan yang sudah dipelajari untuk membuat rumusan masalah agar melatih siswa lebih kreatif dan terampil dalam menuangkan ide sehingga diperoleh banyak kemungkinan penyelesaian dari masing-masing siswa. Menurut Suherman (2008) pemecahan masalah adalah salah satu kompetensi dalam pembelajaran. Selanjutnya berhubungan dengan hal tersebut National Council of Teachers of Mathematics (NCTM, 2000) juga merumuskan tujuan pembelajaran matematika terdiri dari lima kemampuan dasar matematika yaitu, pemecahan masalah (problem solving), penalaran dan bukti (reasoning and proof), komunikasi (communication), koneksi (connections), dan representasi (representation). Berdasarkan hal tersebut maka dalam pembelajaran matematika, pemecahan masalah memiliki fungsi yang penting, karena pembelajaran melalui pemecahan masalah memungkinkan siswa membangun atau mengkontruksi pengetahuannya sendiri didasarkan pengetahuan dan pengalaman yang telah dimiliki.

Kemampuan berpikir kritis siswa dapat dirangsang melalui pembelajaran pemecahan masalah, salah satunya adalah pembelajaran pemecahan masalah matematika open-ended. Menurut Lestari (2013) melalui pembelajaran dengan masalah matematika open-ended kemampuan berfikir kritis siswa dapat terangsang sehingga mereka akan mendapatkan pengalaman dalam proses menemukan jawaban dari suatu masalah. Poppy (2012) mengungkapkan bahwa masalah matematika open-ended adalah masalah atau soal-soal matematika yang memiliki beberapa atau bahkan banyak penyelesaian yang benar dan juga banyak cara untuk menemukan penyelesaiannya.

Pada dunia nyata masih banyak siswa yang belum mampu memahami masalah matematika open-ended sehingga siswa mengalami kesulitan dalam menyelesaikannya karena yang terjadi saat ini masih menyelesaikan matematika dengan rumus belum menyelesaikan masalah. Sebagaimana yang diungkapkan oleh Ruseffendi (2006) bahwa terdapat siswa yang setelah belajar matematika, tidak mampu memahami bahkan pada bagian yang paling sederhana sekalipun, serta banyak konsep yang dipahami secara keliru sehingga matematika dianggap sebagai ilmu yang sukar, ruwet, dan sulit. Selain itu suasana pembelajaran dalam kelas yang ti- 
dak menyenangkan atau penjelasan guru yang membingungkan turut mengambil peran. Salah satu faktor kesulitan siswa dalam menyelesaikan masalah matematika adalah munculnya rasa cemas. Kecemasan siswa dapat disebabkan oleh beberapa faktor, yaitu faktor intelegensi, faktor didalam diri siswa dan faktor lingkungan. Keadaan siswa dimana siswa ketika menghadapi matematika merasa tegang atau cemas disebut dengan kecemasan matematika. Johnson (2006) mendefinisikan kecemasan matematika sebagai suatu perasaan tegang dan cemas yang mengganggu ketika seseorang dihadapkan dengan matematika baik dalam memanipulasi angka maupun dalam pemecahan masalah matematika pada pelajaran ataupun kehidupan sehari-hari. Dengan demikian, kecemasan matematika akan mengganggu proses berpikir, lebih khususnya proses berpikir kritis siswa dalam pembelajaran maupun pemecahan masalah matematika. Lebih lanjut, Stuard dan Laria (2001) mengkatagorikan kecemasan matematika siswa menjadi tiga yaitu kecemasan matematika tinggi, kecemasan matematika sedang, dan kecemasan matematika rendah.

Berdasarkan penelitian yang dilakukan oleh Sherly, A.P. (2019) mengatakan bahwa terdapat pengaruh yang signifikan pada tingkat kecemasan dalam belajar matematika terhadap kemampuan berpikir kritis siswa. Pada penelitian Sherly kategori berpikir kritis menurut Ennis dengan menggunakan materi sistem persamaan linear dua variabel, yang menjadi pembeda dengan penelitian ini adalah kategori berpikir kritis menurut Facione dengan materi volume kubus dan balok untuk tingkat kecemasan matematia sama yaitu, kecemasan matematika tinggi sedang, dan rendah. Berdasarkan sebagaimana yang telah dikemukakan di atas, maka peneliti melakukan penelitian yang berjudul berfikir kritis siswa dalam menyelesaikan soal open-ended ditinjau dari kecemasan matematika.

\section{Metode Penelitian}

Penelitian ini termasuk jenis penelitian deskriptif dengan menggunakan pendekatan kualitatif, dimana penelitian ini dibuat untuk menyajikan gambaran mengenai suatu peristiwa sosial dengan cara mendeskripsikan dalam bentuk paragraf. Subjek pada penelitian ini adalah masing-masing satu siswa, dengan tingkat kecemasan tinggi, sedang, dan rendah. Pemilihan subjek dalam penelitian ini menggunakan purposive sampling yaitu penentuan sampel dengan pertimbangan tertentu. Ketiga 
subjek adalah siswa kelas IX SMP dengan kategori kecemasan matematika. Pemilihan 3 subjek tersebut dilakukan setelah pemberian angket kecemasan matematika.

Teknik pengumpulan data yang digunakan dalam penelitian ini ada tiga yaitu, metode tes, metode angket, dan metode wawancara. Instrumen penelitian yang digunakan dalam penelitian ini adalah : angket kecemasan matematika untuk menentukan subjek penelitian, tes kemampuan pemecahan masalah matematika open-ended yang digunakan dalam mendapatkan data kemampuan berpikir kritis siswa pada pemecahan masalah matematika open-ended yang ditinjau dari kecemasan maematika. Instrumen peneliti mengadopsi dari Angket Hamilton Rating Scale For Anxiety (HARS). Angket kecamasan matematika terdiri dari 14 pernyataan dengan butir pertanyaan yang meminta responden untuk memilih salah satu jawaban yang sesuai dari beberapa jawaban yang disediakan. Instrumen tes pemecahan masalah matematika open-ended berbentuk uraian yang berkaitan dengan volume kubus dan balok. Pedoman wawancara digunakan agar wawacara berjalan efektif dan tetap terfokus pada permasalahan. Hasil tes akan dianalisis menggunakan kriteria berpikir kritis Facione (2011). Berdasarkan kriteria berpikir kritis Facione (2011) yang disesuaikan dengan tahapan pemecahan masalah Polya (1973), maka terdapat indikator yang tersaji pada tabel 1.

Tabel 1. Indikator berpikir kritis dalam pemecahan masalah

\begin{tabular}{|c|c|c|c|}
\hline No. & $\begin{array}{c}\text { Tahapan Pemecahan } \\
\text { Masalah }\end{array}$ & Kriteria Berpikir Kritis & $\begin{array}{c}\text { Indikator Berpikir } \\
\text { Kritis }\end{array}$ \\
\hline \multirow[t]{3}{*}{1.} & \multirow{3}{*}{$\begin{array}{l}\text { Tahap } 1 \\
\text { Memahami masalah }\end{array}$} & \multirow[t]{3}{*}{ Interprestasi } & Kategorisasi \\
\hline & & & Dekode \\
\hline & & & Klarifikasi \\
\hline \multirow[t]{3}{*}{2.} & \multirow{3}{*}{$\begin{array}{l}\text { Tahap } 2 \\
\text { Membuat rencana }\end{array}$} & \multirow[t]{2}{*}{ Analisis } & Identifikasi argumen \\
\hline & & & Analisis argumen \\
\hline & & Evaluasi & Penilaian argumen \\
\hline \multirow[t]{6}{*}{3.} & \multirow{6}{*}{$\begin{array}{l}\text { Tahap } 3 \\
\text { Melaksanakan rencana }\end{array}$} & \multirow[t]{3}{*}{ Inferensi } & Pemikiran alternatif \\
\hline & & & Penarikan kesimpulan \\
\hline & & & Penyelesaian Masalah \\
\hline & & \multirow[t]{3}{*}{ Penjelasan } & Deskripsi masalah \\
\hline & & & Justifikasi prosedur \\
\hline & & & Artikulasi argumen \\
\hline \multirow[t]{2}{*}{4.} & \multirow{2}{*}{$\begin{array}{l}\text { Tahap } 4 \\
\text { Memeriksa kembali }\end{array}$} & \multirow[t]{2}{*}{ Regulasi diri } & Penilaian diri \\
\hline & & & Pengoreksian diri \\
\hline
\end{tabular}

Teknik analisis data diawali dengan analisis data hasil angket kecemasan matematika, dilanjutkan dengan analisis data hasil tes dalam memecahkan masalah matematika open-ended yang berguna sebagai pedoman dalam menyusun pertanyaan untuk wawancara. Analisis data terakhir dilakukan pada hasil 
wawancara yang meliputi reduksi data, penyajian data, dan penarikan data atau verifikasi.

\section{Hasil dan Pembahasan}

Hasil penelitian menunjukkan bahwa subjek menyelesaikan masalah melalui 4 tahapan pemecahan masalah yaitu, memahami masalah, membuat rencana, melaksanakan rencana, dan memeriksa kembali. Subjek juga menjelaskan kriteria berpikir kritis pada materi volume kubus dan balok. Subjek penelitian yang akan diambil dalam penelitian ini masing-masing satu siswa yang memiliki tingkat kecemasan tinggi, sedang, dan rendah. Siswa dengan kecemasan matematika tingkat rendah mendapatkan skor angket $<15$, siswa dengan kecemasan matematika sedang memiliki skor angket 15-36, dan siswa dengan kecemasan matematika tinggi mendapatkan skor angket $>36$. Selanjutnya subjek diberikan soal pemecahan masalah matematika open-ended untuk dikerjakan dan wawancara. Berikut adalah hasil pemecahan masalah yang telah dianalisis berdasarkan kriteria berpikir kritis.

Tabel 2. Hasil Pemecahan Masalah Berdasarkan Kriteria Berpikir Kritis

\begin{tabular}{|c|c|c|c|c|c|c|}
\hline No. & $\begin{array}{c}\text { Tahapan } \\
\text { Pemecahan } \\
\text { Masalah }\end{array}$ & $\begin{array}{c}\text { Kriteria Berpikir } \\
\text { Kritis }\end{array}$ & $\begin{array}{c}\text { Indikator Berpikir } \\
\text { Kritis }\end{array}$ & S1 & $\mathbf{S 2}$ & S3 \\
\hline \multirow[t]{3}{*}{1.} & \multirow{3}{*}{$\begin{array}{l}\text { Tahap } 1 \\
\text { Memahami masalah }\end{array}$} & \multirow[t]{3}{*}{ Interprestasi } & Kategorisasi & $\checkmark$ & $\checkmark$ & $\checkmark$ \\
\hline & & & Dekode & $\checkmark$ & $\checkmark$ & $\checkmark$ \\
\hline & & & Klarifikasi & $\checkmark$ & $\checkmark$ & $\checkmark$ \\
\hline \multirow[t]{3}{*}{2.} & \multirow{3}{*}{$\begin{array}{l}\text { Tahap } 2 \\
\text { Membuat rencana }\end{array}$} & \multirow[t]{2}{*}{ Analisis } & Identifikasi argument & $\checkmark$ & $\checkmark$ & $\sqrt{ }$ \\
\hline & & & Analisis argumen & $\checkmark$ & $\checkmark$ & $\checkmark$ \\
\hline & & Evaluasi & Penilaian argumen & $\checkmark$ & $\checkmark$ & $\checkmark$ \\
\hline \multirow[t]{6}{*}{3.} & \multirow{6}{*}{$\begin{array}{l}\text { Tahap } 3 \\
\text { Melaksanakan } \\
\text { rencana }\end{array}$} & \multirow[t]{3}{*}{ Inferensi } & Pernikiran alternatif & - & - & $\checkmark$ \\
\hline & & & Penarikan kesimpulan & - & - & $\checkmark$ \\
\hline & & & Penyelesaian Masalah & - & - & $\checkmark$ \\
\hline & & \multirow[t]{3}{*}{ Penjelasan } & Deskripsi masalah & $\checkmark$ & $\checkmark$ & $\checkmark$ \\
\hline & & & Justifikasi prosedur & $\checkmark$ & $\checkmark$ & $\checkmark$ \\
\hline & & & Artikulasi argumen & $\checkmark$ & $\checkmark$ & $\checkmark$ \\
\hline \multirow[t]{2}{*}{4.} & \multirow{2}{*}{$\begin{array}{l}\text { Tahap } 4 \\
\text { Memeriksa kembali }\end{array}$} & \multirow[t]{2}{*}{ Regulasi diri } & Penilaian diri & - & $\checkmark$ & $\checkmark$ \\
\hline & & & Pengoreksian diri & & $\checkmark$ & $\checkmark$ \\
\hline
\end{tabular}


1. Siswa dengan kecemasan matematika tinggi (S1)

Hasil tes pemecahan masalah matematika open-ended dengan kecemasan matematika tinggi dapat dilihat pada gambar 1.

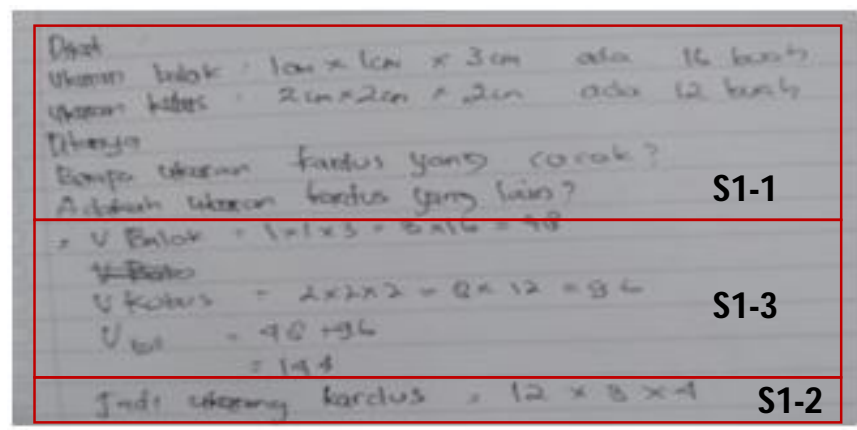

Gambar 1. Hasil Tes Siswa dengan Kecemasan Matematika Tinggi Pada soal tersebut S1 telah mampu memahami masalah, ditunjukkan dengan menuliskan kembali rumusan masalah dari masalah yang diberikan menggunakan bahasanya sendiri. Rumusan masalah ini terdiri dari apa yang diketahui dan ditanyakan dari masalah. Kemudian S1 dalam menjelaskan kriteria berpikir kritis (S1-1) dimana, S1 dapat mengetahui dan mengembangkan makna mengenai permasalah yang diajukan (kategorisasi), mengemukakan rumusan masalah menggunakan bahasanya sendiri (dekode), mengungkapkan istilah-istilah yang dipakai (klarifikasi).

Selanjutnya pada tahap pemecahan masalah yang kedua dan ketiga, S1 mampu membuat rencana dan namun kurang mampu untuk melaksanakan rencana dengan baik karena S1 tidak dapat menentukan ukuran kardus lainnya yang memuat kubus dan balok kayu. Strategi yang digunakan S1 dengan mencari volume total dari kubusdan balok kayu kemudian mencari ukuran kardus yang sesuai dengan volume total tersebut (S1-2). Kemudian untuk penyelesaian terlihat pada jawaban siswa dengan kode (S1-3). S1 juga menjelaskan kriteria berpikir kritis dalam tahapan membuat rencana dan melaksanakan rencana. Dimana S1 dapat memberikan argumentasi mengenai hasil dari rumusan masalah yang telah dibuat (identifikasi argumen), menentukan dan menerapkan strategi pemecahan masalah yang dibuat (analisis argumen), dan memperhatikan hal-hal penting dalam membuat rencana dengan memeriksa strategi pemecahan masalah yang akan digunakan apakah masalah dapat terpecahkan atau tidak (penilaian argumen). Kemudian dalam melaksanakan rencana, S1 mampu menghubungkan semua informasi yang 
diperoleh dengan menggunakan tahapan pemecahan masalah dalam penyelesaiannya (deskripsi), menjelaskan langkah-langkah yang diambil ketika melakukan penyelesaian (justifikasi), mengungkapkan argumentasi siswa memilih langkah tersebut dalam menyelesaikan masalah (artikulasi), namun S1 kurang mampu memperhatikan hal-hal penting dalam tahapan pemecahan masalah yang digunakan dalam penyelesaian masalah, menentukan kesimpulan yang benar berdasarkan rumusan masalah pada soal (penarikan kesimpulan) dan tidak dapat mengungkapkan penyelesaian yang lain (pemikiran alternatif).

Pada soal tersebut tahap terakhir yaitu memeriksa kembali, S1 kurang mampu memeriksa kembali hasil penyelesaian karena ukuran kardus yang ditemukan tidak dapat memuat kubus dan balok kayu dengan rapi dan penuh. Hal ini menyebabkan S1 tidak dapat menjelaskan kriteria dalam berpikir kritis.

2. Siswa dengan kecemasan matematika sedang (S2)

Jawaban tes pemecahan masalah matematika open-ended dengan kecemasan matematika sedang dapat dilihat pada gambar 2 .

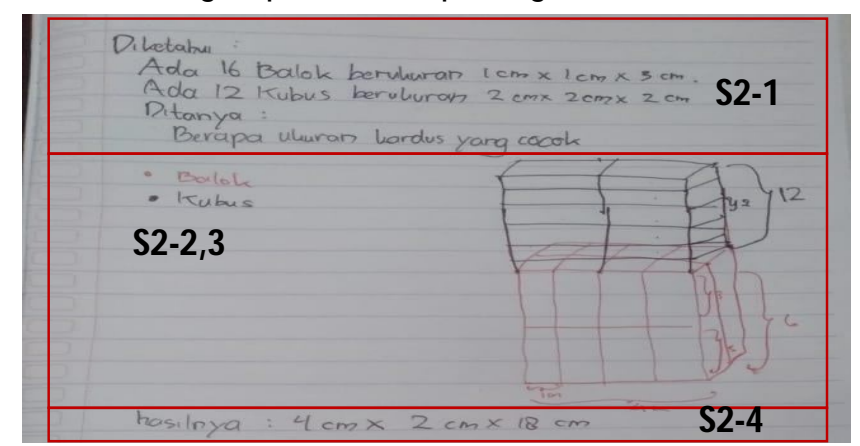

Gambar 2. Hasil Tes Siswa dengan Kecemasan Matematika Sedang Pada soal tersebut S2 telah mampu memahami masalah, ditunjukkan dengan menuliskan kembali rumusan dari masalah yang diberikan menggunakan bahasanya sendiri. Rumusan masalah ini terdiri dari apa yang diketahui dan ditanyakan dari masalah. Kemudian S2 dalam menjelaskan kriteria berpikir kritis (S2-1) dimana, S2 mengetahui dan mengembangkan makna mengenai permasalah yang diajukan (kategorisasi), mengemukakan rumusan masalah menggunakan bahasanya sendiri (dekode), menjelaskan istilah-istilah yang dipakai (klarifikasi).

Selanjutnya pada tahapan pemecahan masalah yang kedua dan ketiga, S2 
mampu membuat rencana dan namun kurang mampu untuk membuat rencana dengan baik karena S2 tidak dapat menentukan ukuran kardus lainnya yang memuat kubus dan balok kayu. Strategi yang digunakan S2 dengan membuat gambaran kardus yang memuat balok dan kubus kayu. Kemudian untuk penyelesaian terlihat pada jawaban siswa dengan kode (S2-2,3). S2 juga menjelaskan kriteria berpikir kritis dalam tahapan membuat rencana dan melaksanakan rencana. S2 dapat memberikan argumentasi mengenai hasil dari rumusan masalah yang telah dibuat (identifikasi argumen), menentukan dan menerapkan strategi pemecahan masalah yang digunakan (analisis argumen), dan memperhatikan hal-hal penting dalam membuat rencana dengan memeriksa strategi pemecahan masalah yang akan digunakan apakah masalah dapat terpecahkan atau tidak (penilaian argumen). Kemudian dalam melaksanakan rencana S2 mampu menghubungkan semua informasi yang diperoleh dengan tahapan pemecahan masalah dalam penyelesaiannya (deskripsi), menjelaskan langkah-langkah yang diambil ketika melakukan penyelesaian (justifikasi), mengungkapkan argumentasi siswa memilih langkah tersebut dalam menyelesaikan masalah (artikulasi), namun S2 kurang mampu mengetahui dan memperhatikan hal-hal penting dalam tahapan pemecahan masalah yang digunakan dalam penyelesaian masalah, menentukan kesimpulan yang benar berdasarkan rumusan masalah pada soal (penarikan kesimpulan) dan tidak dapat mengungkapkan alternatif penyelesaian yang lain (pemikiran alternatif).

Pada soal tersebut tahap terakhir yaitu memeriksa kembali, S2 mampu memeriksa kembali hasil penyelesaiannya dan membuktikan bahwa ukuran kardus tersebut dapat memuat kubus dan balok kayu dengan rapi dan penuh melalui gambar walaupun penyelesaiannya belum tuntas. Kemudian S2 menjelaskan kriteria berpikir kritis yaitu regulasi diri (S2-4). Dimana S2 dapat menyelesaikan strategi yang digunakan (penilaian diri), dan meninjau kembali penyelesaian yang telah dilakukan sebelum menentukan kesimpulan akhir (pengoreksian diri).

3. Siswa dengan kecemasan matematika rendah (S3)

Jawaban tes pemecahan masalah matematika open-ended dengan kecemasan matematika rendah dapat dilihat pada gambar 3 . 


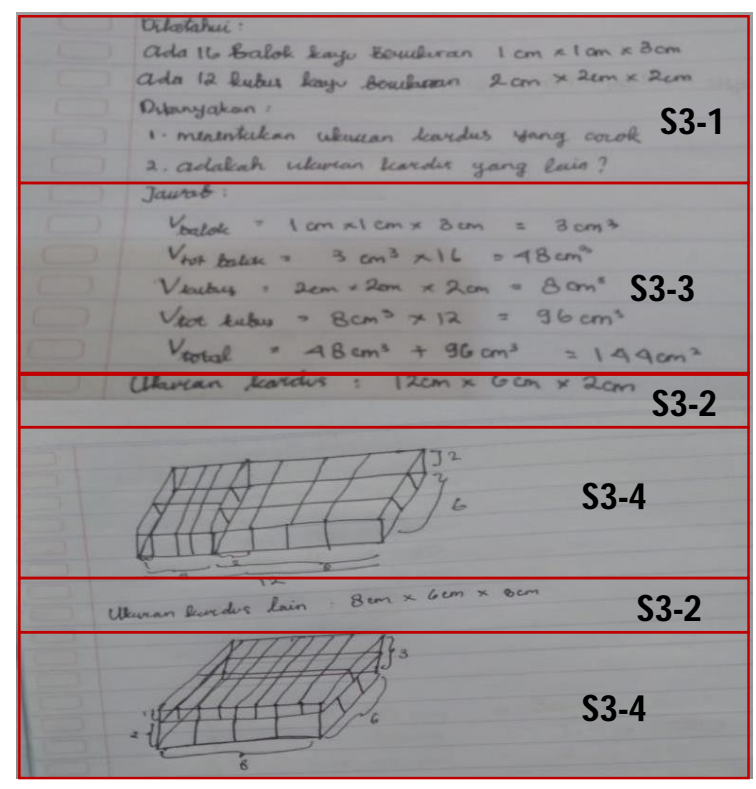

Gambar 3. Hasil Tes Siswa dengan Kecemasan Matematika Rendah

Pada soal tersebut S3 telah mampu memahami masalah, ditunjukkan dengan menuliskan kembali rumusan masalah dari masalah yang diberikan menggunkan bahasanya sendiri. Rumusan masalah ini terdiri dari apa yang diketahui dan ditanyakan dari masalah. Kemudian S3 dalam menjelaskan kriteria berpikir kritis (S3-1) dimana, S3 dapat mengetahui dan mengembangkan makna mengenai permasalah yang diajukan (kategorisasi), mengemukakan rumusan masalah menggunakan bahasanya sendiri (dekode), menjelaskan istilah-istilah yang digunakan (klarifikasi).

Selanjutnya pada tahapan pemecahan masalah yang kedua dan ketiga, S3 dapat menyusun rencana serta melaksanakan rencana dengan benar. Strategi yang digunakan S3 dengan mencari volume total dari kubus dan balok kayu kemudian mencari ukuran kardus yang sesuai dengan volume total tersebut dan mengoreksi kembali dengan membuat gambaran. kemudian untuk penyelesaian terlihat pada jawaban siswa dengan kode (S3-3). S3 juga menjelaskan kriteria berpikir kritis dalam tahapan membuat rencana dan melaksanakan rencana. Dimana S3 dapat memberikan argumentasi mengenai hasil dari rumusan masalah yang telah dibuat (identifikasi argumen), menentukan dan menerapkan strategi pemecahan masalah yang digunakan (analisis argumen), dan memperhatikan hal-hal penting dalam membuat rencana dengan memeriksa strategi pemecahan masalah yang akan digunakan apakah 
masalah dapat terpecahkan atau tidak (penilaian argumen). Kemudian dalam melaksanakan rencana S3 mampu mengetahui dan memperhatikan hal-hal penting dalam tahapan pemecahan masalah (penyelesaikan masalah), menghubungkan semua informasi yang diperoleh dengan tahapan pemecahan masalah yang digunakan dalam penyelesaiannya (deskripsi), menjelaskan langkah-langkah yang diambil ketika melakukan penyelesaian (justifikasi), mengungkapkan argumentasi siswa memilih langkah tersebut dalam menyelesaikan masalah (artikulasi), menentukan kesimpulan yang benar terjadi rumusan masalah dalam soal (penarikan kesimpulan), dan dapat mengungkapkan alternatif penyelesaian yang lain (pemikiran alternatif).

Pada soal tersebut tahap terakhir yaitu memeriksa kembali, S3 mampu memeriksa kembali hasil penyelesaiannya dan membuktikan bahwa ukuran kardus tersebut dapat memuat kubus dan balok kayu dengan rapi dan penuh (S3-4). Kemudian dalam memeriksa kembali ini S3 menjelaskan kriteria berpikir kritis yaitu regulasi diri. Dimana S3 dapat menyelesaikan strategi yang dilakukan dengan baik (penilaian diri), dan meninjau kembali penyelesaian yang telah dilakukan sebelum menentukan kesimpulan akhir (pengoreksian diri).

\section{Kesimpulan}

Berdasarkan hasil dan pembahasan maka disimpulkan bahwa siswa yang memiliki kecemasan matematika tinggi dapat memahami masalah, membuat rencanakan, namun kurang mampu dalam melakukan rencana serta memeriksa kembali karena subjek tidak dapat menyelesaikan masalah dengan baik dengan tidak ditemukannya ukuran kardus yang lain, kemudian juga ukuran kardus yang ditemukan ternyata tidak dapat memuat kubus dan balok kayu dengan penuh dan rapi. Siswa dengan kecemasan matematika tinggi dapat mememuhi kriteria berpikir kritis interpretasi, analisis, evaluasi, dan penjelasan, tetapi kurang mampu memenuhi kriteria berpikir kritis inferensi dan regulasi diri, karena subjek tidak dapat melakukan penarikan kesimpulan dengan tepat, tidak menemukan alternatif jawaban lain dari masalah yang diberikan dan juga tidak mengoreksi kembali apakah langkah yang ditentukan sudah benar atau belum dengan tidak termuat penuh dan rapi balok dan kubus kayu yang dimasukkan ke dalam kardus.

Siswa yang memiliki kecemasan matematika sedang dapat memahami masalah, membuat rencanakan, dan memeriksan kembali namun kurang mampu dalam melaksanakan rencana. karena subjek tidak dapat menyelesaikan masalah dengan 
baik dengan tidak ditemukannya ukuran kardus yang lain. Siswa dengan kecemasan matematika tinggi dapat mememuhi kriteria berpikir kritisi nterpretasi, analisis, evaluasi, penjelasan, dan regulasi diri, namun kurang mampu memenuhi kriteria berpikir kritis inferensi, karena subjek tidak menemukan alternatifjawaban lain dari masalah yang diberikan.

Siswa yang memiliki kecemasan matematika rendah dapat memahami masalah, membuat rencana, melaksanakan rencana dan memeriksa kembali karena subjek dapat menyelesaikan masalah dengan baik dengan ditemukannya ukuran kardus yang lain. Siswa dengan kecemasan matematika tinggi dapat memenuhi kriteria berpikir kritis interpretasi, analisis, evaluasi, inferensi, penjelasan, dan regulasi diri.

Saran hasil penilitian ini diharapkan peran guru di kelas saat pembelajaran dapat menggunakan model pembelajaran yang menyenangkan untuk dapat menciptakan suasana yang efektif. Dengan demikian, guru dapat mengasah kemampuan berpikir kritis serta meningkatkan kemampuan memecahkan masalah pada siswa. Salah satunya, pada pembelajaran di kelas guru memberikan latihan soal yang memiliki kompetensi pemecahan masalah supaya siswa terlatih dalam mengerjakan soal pemecahan masalah.

\section{Daftar Pustaka}

Aizikovith-undi,E and Cheng, Diana. 2015. Developing Critical Thingking Skill from Dispositions to Abilities : Mathematics Education from Early Childhood to High School. Scientific Research Publishing. Vol. 6 pp 455-462.

Facione, Peter. 2011. Critical Thingking What It Is and Why It Counts. Insight Assesment.

Johnson Elaine. 2006. Contextual Teaching and Learning. Bandung: Mizan Media Utama.

Lestari, Sri. 2013. Proses Berpikir Kritis Siswa dalam Memecahkan Masalah Matematika Open-Ended ditinjau dari Kemampuan Matematika Perbedaan Jenis Kelamin Pada Materi Kubus dan Balok. E-Journal Unesa. Vol. 2(5).

NCTM. 2000. Principles and Standard for School Mathematics. USA : Library of Congress Cataloguing-in-Publication Data.

Polya, G. 1973. How to Solve IT. New Jersey : Princenton University Press.

Poppy, Yulianti. 2012. Pengaruh Model Pembelajaran Auditory, Intelectually, And Repetition (AIR) Terhadap Kemampuan Penalaran Matematis Siswa SMP. Bandung : Universitas Pasundan Bandung.

Ruseffendi. 2006. Pengantar Kepada Membantu Guru Mengembangkan Kompetens- 
inya dalam Pengajaran Matematika. Bandung: Tarsito.

Sherly, A.P. 2019. Kemampuan Berpikir Kritis Siswa dalam Menyelesaikan Masalah Matematika dibedakan dari Tingkat Kecemasan. Skripsi, tidak dipublikasikan Universitas Islam Negeri Sunan Ampel Surabaya.

Shimizu, N. 2000. An analysis of 'Make an Organized List' Strategy in Problem Solving Process". In T.Nakahara \& M. Koyama (Eds.) Proceedings of the 24th Conference of the International Group for the Psychology of Mathematics Education, Vol. 4 (289-296). Hiroshima : Hiroshima University

Suherman. 2008. Belajar dan Pembelajaran Matematika. Bandung : UPI FPMIPA.

Struad, G. W. \& Laria, M. T. 2001. Principles and Practice of Psychiatric Nursing. St. Louis : Mosby Book Inc

Yamada, A. 2000. Two Paterus of Problem Solving Process from a Representational Perspective. In T. Nakahara \& M. Koyama (Eds.) Proceedings of the 24th Conference of the International Group for the Psychology of Mathematics Education, Vol. 4 (289-296). Hiroshima: Hiroshima University 